\title{
PENERAPAN PROGRAM RUMAH PANGAN LESTARI DI KOMPLEK PERUMAHAN BTN BINA HARAPAN DAN PERUMNAS UNIB KOTA BENGKULU
}

\section{IMPLEMENTATION OF SUSTAINABLE FOOD HOUSE IN RESIDENTIAL COMPLEX OF BINA HARAPAN BTN AND PERUMNAS UNIB CITY BENGKULU}

\author{
Oleh: \\ Puji Harsono, Bambang Sumantri, Prasetyo \\ Fakultas Pertanian Universitas Bengkulu \\ pharsono_skh@yahoo.com
}

\begin{abstract}
Strengthening food security can be started at the household level, one way is through the program Sustainable Food House (RPL). Sustainable Food Houses Program in urban residential areas is one way of creative, innovative and environmentally friendly to realize the green area in the yard of a residential beautiful, cool and productive. How this is done by utilizing the pot wheelbase (wick pot) on a semi-organic vegetable production. IbM activities of community groups to inspire citizens and public housing complexes around the housing to apply RPL through the pot wheelbase in the cultivation of vegetables in home gardens urban areas. Utilization of open space with vegetable crops, in addition to economic value, it also creates a healthy and educational environment for the citizens housing complex BTN Hope and Housing Development UNIB. The results of the activities IbM the RPL program is able to evoke the spirit of the citizens in an effort to greening the housing area. This is evidenced by the use of the home page and all along the road on both the housing. It also provides technical skills of residents in the cultivation of vegetables in the pot so that the need for some types of vegetables for his family adequately met from the application of science and technology activities for the community by a team of professors from the University of Bengkulu.
\end{abstract}

Keywords: green areas, sustainable food home, wick pot, vegetables

\section{PENDAHULUAN}

Pekarangan rumah di komplek perumahan perkotaan umumnya memiliki lahan terbuka yang sempit dan halamannya didominasi oleh paving blok atau lantai semen. Lantai semen atau paving block menjadikan halaman bersih dan tidak becek pada musim penghujan, namun demikian keberadaannya juga dapat menimbulkan masalah lingkungan diantaranya adalah; mengurangi resapan air hujan ke dalam tanah, permukaan lantai semen yang berwarna cerah dapat memantulkan radiasi matahari sehingga menimbulkan peningkatan suhu udara di sekitarnya.

Komplek perumahan BTN Bina Harapan RT 3/RW 1 dihuni sebanyak 45 kepala keluarga, mayoritas warganya adalah pegawai negeri sipil dan sisanya adalah wiraswasta. Sedangkan komplek Perumnas Unib di RT 13/RW 3 mempunyai 48 kepala keluarga yang 
sebagian besar adalah dosen dan karyawan Universitas Bengkulu. Sumberdaya manusia di kedua komplek perumahan tersebut sangat memadai karena jenjang pendidikannya minimal Strata 1, bahkan di Perumnas Unib banyak yang S2 maupun S3 yang kompeten di bidangnya masing-masing.

Sedikitnya vegetasi, buruknya resapan air ke dalam tanah dan rapatnya jarak antar rumah menciptakan sirkulasi udara kurang baik disekitarnya, suasana gersang, dan meningkatnya suhu udara yang menyebabkan masalah lingkungan seperti banjir pada saat hujan dan panas ketika cuaca cerah. Salah satu upaya kreatif, inovatif dan ramah lingkungan untuk mengatasi masalah lingkungan di komplek perumahan tersebut adalah teknik budidaya tanaman sayuran semi-organik di dalam pot kapiler (tasulampoter) dengan memanfaatkan pekarangan disekitar rumah. Kegiatan pengabdian kepada masyarakat skim Ipteks bagi masyarakat (IbM) dalam bentuk budidaya tanaman sayuran dalam pot kapiler atau tasulampoter diharapkan mampu menciptakan kawasan hijau pemukiman (green village), pemenuhan gizi nabati keluarga secara mandiri, konservasi lengas tanah dan peningkatan pendapatan serta kesejahteraan masyarakat.

Kemandirian pangan adalah kemampuan negara dan bangsa dalam memproduksi pangan yang beraneka ragam dari dalam negeri yang dapat menjamin pemenuhan kebutuhan pangan yang cukup sampai tingkat perseorangan dengan dengan memanfaatkan potensi sumberdaya alam, manusia, sosial, ekonomi, dan kearifan lokal secara bermartabat (UU RI Nomor 18 Tahun 2012 Tentang Pangan). Esensi dari amanat undang-undang tersebut adalah terpenuhinya pangan bagi setiap rumah tangga merupakan tujuan sekaligus sebagai sasaran dari ketahanan pangan di Indonesia. Namun demikian, disadari bahwa perwujudan ketahanan pangan perlu memperhatikan sistem hierarki mulai dari tingkat global, nasional, regional, wilayah, rumah tangga dan individu (Simatupang, 2006).

Rumah Pangan Lestari (RPL) menurut Kementerian Pertanian (2011), adalah rumah penduduk yang mengusahakan pekarangan secara intensif untuk dimanfaatkan dengan berbagai sumberdaya lokal secara bijaksana yang menjamin kesinambungan penyediaan bahan pangan rumah tangga yang berkualitas dan beragam. Sebelumnya, Rachman dan Ariani (2007) menyebutkan bahwa tersedianya pangan yang cukup secara nasional maupun wilayah merupakan syarat keharusan dari terwujudnya ketahanan pangan nasional, namun itu saja tidak cukup, syarat kecukupan yang harus dipenuhi adalah terpenuhinya kebutuhan pangan di tingkat rumah tangga/individu.

Sayuran merupakan sumber gizi protein nabati, vitamin dan mineral yang diperlukan oleh tubuh manusia. Kekurangan vitamin dapat menimbulkan penyakit rabun mata, beriberi, kulit dan malnutrisi yang mengganggu kesehatan tubuh. Bagian yang dikonsumsi dari tanaman sayuran dapat dari bagian yang dapat dimakan seperti; sayuran umbi (bawang merah), buah (tomat, terung, cabai), dan daun (selada). Tanaman sayuran masuk dalam kelompok ilmu hortikultura bersama-sama dengan tanaman buah-buahan, tanaman hias dan tanaman obat (biofarmaka). Sebagaian besar sayuran dikonsumsi dalam bentuk segar, namun demikian ada beberapa yang dikonsumsi dalam bentuk awetan walaupun sudah berbeda dari segi rasa, aroma dan kandungan nilai gizinya. 
Keterbatasan budidaya tanaman sayuran di komplek perumahan perkotaan adalah lahan yang sempit dan "semenisasi" halaman atau pekarangan rumah, untuk itu penanaman sayuran menggunakan pot atau polibag merupakan salah pilihan warganya. Media tanam dalam pot perlu dibuat sesubur mungkin untuk mendukung pertumbuhan dan perkembangan tanaman sejak pembibitan hingga panen, salah satunya dengan aplikasi bahan organik. Arang-bio juga termasuk bahan organik yang dapat meningkatkan kesuburan tanah, sehingga sangat baik digunakan dalam campuran medium tanam selain tanah dan pupuk kandang. Menurut Lehman (2007), arang-bio dapat digunakan untuk memperbaiki struktur tanah, kesuburan tanah, meningkatkan retensi air dan mineral, menurunkan aliran permukaan (run off) nutrisi, meningkatkan efisiensi pemupukan, serta meningkatkan produksi biomassa tanaman.

Pot bersumbu merupakan pot yang bagian dasarnya dipasang sumbu yang jumlahnya tergantung dari jenis tanamannya. Unit pot bersumbu terdiri dari dua bagian yaitu pot bagian atas untuk medium tanam dan tempat tanaman tumbuh sedangkan bagian bawah berupa ember/baki tempat larutan nutrisi yang diperlukan untuk pertumbuhan dan perkembangan tanaman. Prinsip kerja pot bersumbu menurut Eliades (2010) adalah sumbu pot mengabsorbsi air dan larutan nutrisi secara kapiler. Sebelumnya dilaporkan Bainbridge, (2007) bahwa pot bersumbu yang digunakan untuk budidaya tanaman sayuran mempunyai beberapa keuntungan yaitu mengurangi konsumsi air oleh tanaman, efisien biaya, waktu dan tenaga kerja karena self watering dan self nutrient artinya tanaman "mengairi dan memupuk sendiri" sesuai dengan kebutuhannya, akar tanaman terhindar dari cekaman kelebihan atau kekurangan air dan nutrisi tanaman. Wick pot atau pot bersumbu juga dikenal dengan istilah self draining pot (Perazzini, 2012).

Untuk mewujudkan kawasan perumahan perkotaan yang hijau (green village), produktif dan meningkatnya kesadaran warga perumahan dalam memanfaatkan pekarangan bersemen dengan teknik budidaya sayuran semiorganik dalam pot bersumbu di komplek perumahan BTN Bina Harapan dan Perumnas Unib RT 3/RW 1 dan RT 12/RW 3.

\section{METODE PENGABDIAN}

Penerapan Program Rumah Pangan Lestari di Komplek Perumahan BTN Bina Harapan dan Perumnas Unib Kota Bengkulu pada bulan Mei - Agustus 2015. Metode yang diterapkan untuk merealisasikan program pengabdian kepada masyarakat dalam bentuk penyuluhan pemanfaatan bahan organik, pembuatan model protipe pot bersumbu, pelatihan pembuatan arang-bio sekam, demplot bibit sayuran, pelatihan teknik budidaya bertanam sayuran di dalam pot bersumbu dan tata letaknya di lingkungan komplek perumahan perkotaan.

Penyuluhan yang dilakukan melibatkan masing-masing 15 peserta ibu-ibu di kedua komplek perumahan yang sudah ditentutakan RT dan RW nya. Metode penyuluhan adalah ceramah dengan menggunakan media cetak (hand out), elektronik (power point, slide) dan alat peraga maupun model tanaman yang terkait dengan Tasulampot. Pelatihan dilakukan 
untuk meningkatkan keterampilan warga terkait, tidak hanya keterampilan teknis Tasulampot tetapi juga keterampilan berpikir sehingga peserta mampu memecahkan masalah, membuat keputusan, berpikir kritis dan berpikir kreatif. Meningkatnya kemampuan peserta dalam berpikir dan menguasai teknik budidaya sayuran dalam pot diharapkan dapat mempercepat program green village dan sekaligus memotivasi warga di RT/RW lain. Handbook of The Center for Teaching and Learning, Stanford University (2007) menyebutkan tiga hal penting dalam active learning (AL), yaitu; AL memacu berpikir independen, kritis dan kreatif; AL merangsang kolaborasi; AL meningkatkan motivasi, investment dan performansi.

\section{HASIL DAN PEMBAHASAN}

Program pengabdian kepada masyarakat melalui Ipteks bagi masyarakat ( $\mathrm{IbM}$ ) yang dilakukan melalui penyuluhan, demonstrasi pembibitan, pelatihan yang melibatkan warga BTN Bina Harapan RT 3/RW 1 dan Perumnas Unib di RT 13/RW 3 Kota Bengkulu terlaksana dengan baik. Hal ini dibuktikan dengan terwujudnya lingkungan pemukiman yakni halaman paving block lingkungan rumah warga digunakan untuk budidaya sayuran semiorganik terutama di depan rumah dan pinggir jalan sehingga nampak asri dan produktif.

\section{Kegiatan Penyuluhan}

Metode ceramah digunakan untuk menyampaikan materi dan informasi mengenai kawasan pemukiman dan teknik budidaya sayuran dalam pot bersumbu. Ceramah dilaksanakan dengan bantuan media instruksional yakni berupa power point materi penyuluhan yang ditayangkan menggunakan LCD projector. Menurut Sopah et al., (1986) visualisasi materi dapat membantu; mengatasi hambatan bahasa lokal dalam berkomunikasi, menyusun materi secara baik, memilih ide-ide kunci yang penting, menghemat waktu dan tidak menyimpang dari alur pembicaraan. Penyuluhan diikuti warga terpilih di Perumnas Unib di RT 13/RW 3 dan BTN Bina Harapan RT3/RW 1 sebagai mitra Tim dosen Uni Gambar 1. Peserta penyuluhan rumah pangan lestari di Perumnas Unib \& BTN Bina.

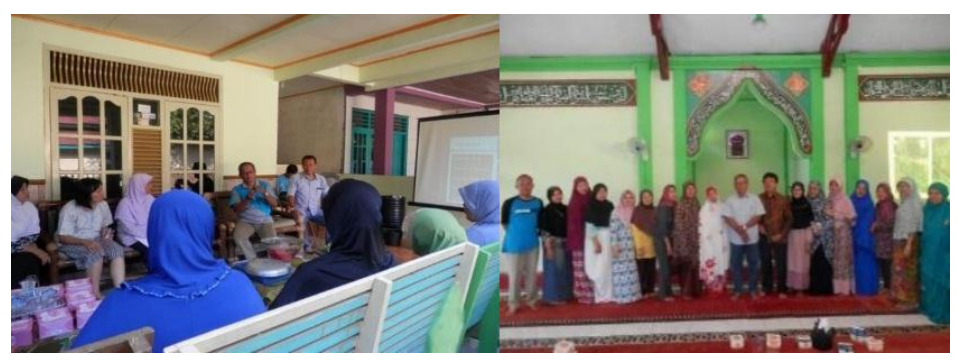

Gambar 1. Warga BTN Bina Harapan dan Perumnas Unib 
Peserta penyuluhan diberikan hand out tentang teknik budidaya berbagai sayuran (tomat, cabai, dan terung ungu), pemeliharaan, teknik pemanenan, pengendalian hama/ penyakit tanaman, pemanfaatan bahan organik berupa pupuk kandang. Selain itu juga diberikan materi tentang keunggulan pot bersumbu dibanding pot biasa.

Selain penyuluhan dengan metode ceramah, tim IbM Universitas Bengkulu juga melakukan demonstrasi pembuatan pot bersumbu dan teknik transplanting sayuran, demonstrasi dilakukan untuk meningkatkan daya serap peserta kegiatan (Gambar 2).

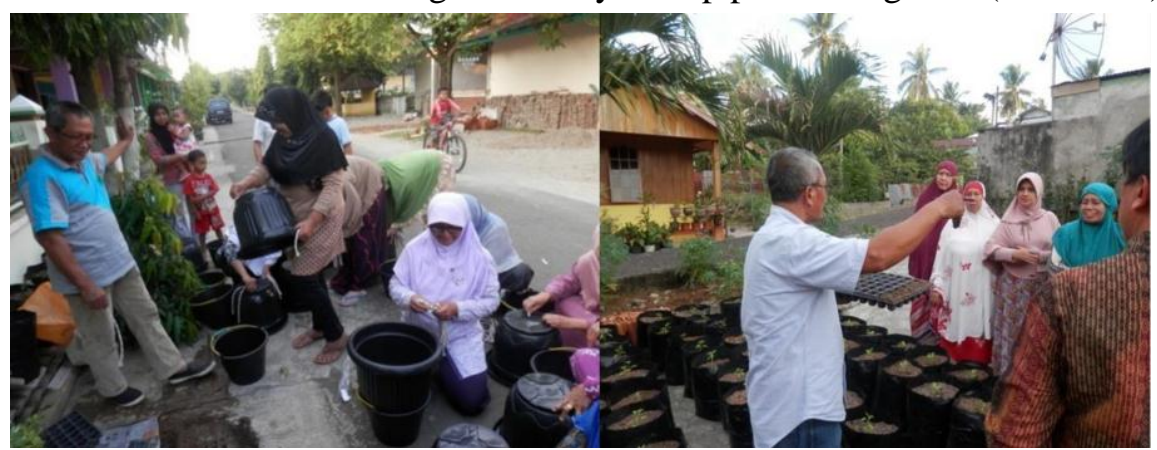

Gambar 2. Peragaan pemasangan pot bersumbu dan teknik transplanting cabai

Untuk mengalihkan fokus materi kepada peserta IbM agar lebih aktif, ceramah diselingi dengan tanya jawab sehingga orientasi tidak didominasi oleh penceramah dari tim dosen. Selain itu, pada waktu menjelang penutup penyuluhan juga diselingi diskusi sebagai cara untuk mengetahui apakah materi yang telah disampaikan dapat dipahami peserta.

Berdasarkan pengamatan dan evaluasi tim IbM dapat disampaikan bahwa peserta mampu memahami materi yang disampaikan dengan baik. Hal ini bisa dibuktikan dengan terlibatnya semua peserta aktif dan antusias dalam pembuatan pot bersumbu, pengisian media ke dalam pot dan memindahkan bibit sayuran dari pot tray (Gambar 2). Dengan demikian warga di kedua kompleks perumahan melakukan active learning yaitu proses belajar dimana peserta mendapat kesempatan untuk lebih banyak melakukan aktivitas belajar, berupa hubungan interaktif dengan materi sehingga terdorong untuk menyimpulkan pemahaman daripada hanya sekedar menerima materi yang diberikan.

\section{Pelatihan Teknik Pembibitan Sayuran}

Tim dosen menyadari bahwa transfer Ipteks hanya dengan penyuluhan saja tentu kurang memadai, untuk itu diberikan beberapa kegiatan pelatihan yang dapat menunjang terwujudnya green village. Kegiatan yang telah dilakukan adalah pembuatan media pembibitan, teknik pembibitan sayuran menggunakan pottray dan penanaman dalam wick pot di halaman rumah bersemen/ paving block. Aktivitas mitra IbM dalam mengikuti berbagai pelatihan dapat dilihat pada Gambar 3. 


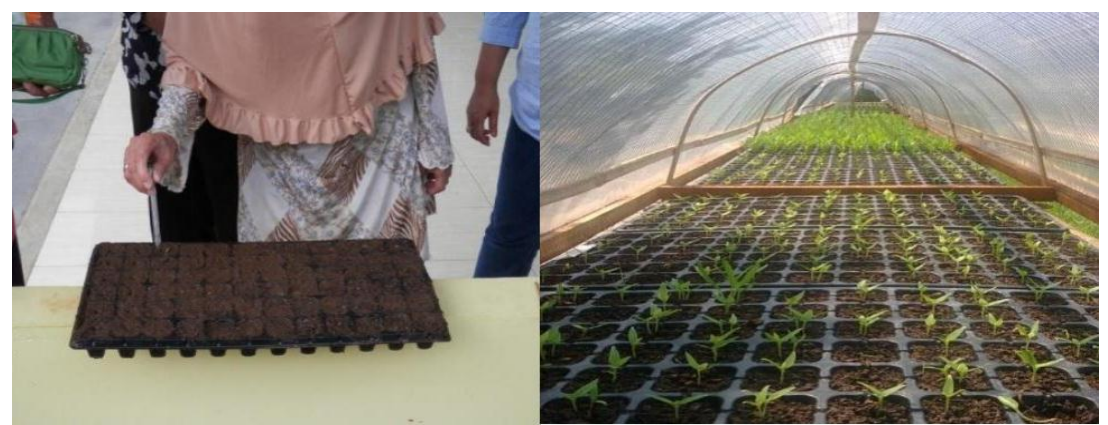

Gambar 3. Keterlibatan warga dalam pembibitan sayuran dengan daya kecambah $90 \%$

Selain mendapatkan Ipteks pembibitan, tim mitra juga dibekali dengan pemanfaatan bahan organik sebagai campuran media tanam diantaranya adalah arang-bio dari sekam padi. Menurut Lehman, (2007) melaporkan bahwa arang-bio dapat digunakan untuk memperbaiki struktur tanah, kesuburan tanah, meningkatkan retensi air dan mineral, menurunkan aliran permukaan (run off) nutrisi, meningkatkan efisiensi pemupukan. serta meningkatkan produksi biomassa tanaman. Keterampilan membuat arang-bio sekam telah didapatkan Tim Guru dari Tim Dosen (Gambar 4).

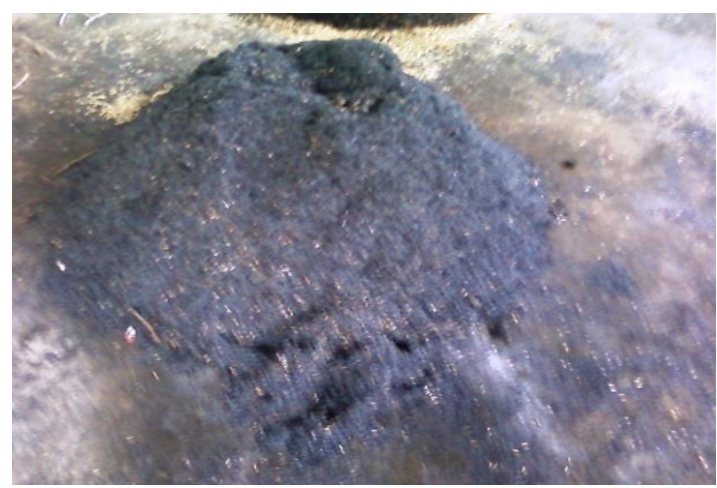

Gambar 4. Tim mitra IbM membuat arang-bio dari sekam padi

Hasil kegiatan pembibitan berbagai sayuran yang dilakukan warga Perumnas Unib di RT 13/RW 3 dan BTN Bina Harapan RT3/RW 1sangat baik karena mampu memberikan motivasi kepada warga di RT lain di lingkungan perumahan tersebut untuk belajar budidaya sayuran.

Apabila pembibitan dikelola dengan sistem agribisnis tentunya bisa menjadi income generating pihak sekolah. Selain itu, pipa pirolisis untuk membuat arang-bio yang diberikan tim dosen PT juga dapat digunakan untuk memproduksi sekam arang dan dijual dalam kemasan $2 \mathrm{~kg}$ untuk dipasarkan ke kios tanaman hias sehingga menumbuhkan enterpreneurship warga. Penggunaan bahan organik juga mengurangi penggunaan pupuk kimia sehingga dampak negatif bagi lingkungan tanah dapat dikurangi dan yang jelas juga mengurangi ongkos produksi.

Beberapa keuntungan penggunaan pot tray semai dibandingkan dengan pembibitan konvensional menggunakan bedengan atau polibag semai; pertumbuhan bibit seragam, efisien media tanam dan tenaga kerja, memudahkan pemeliharaan dan pengangkutan bibit serta efisiensi lahan pembibitan. Contohnya: rak pembibitan sepanjang $16 \mathrm{~m}$ dengan lebar 
$75 \mathrm{~cm}$ mampu menghasilkan 4.284 bibit sayuran dalam 42 pottray, jumlah lubang tanam 102 buah per pottray.

Diharapkan apabila warga mitra IbM kontinyu dalam membuat bibit sayuran berkualitas dan nursery management yang baik maka usaha mewujudkan kawasan pemukiman ramah lingkungan yang asri, indah dan produktif menjadi kenyataan.

\section{Pelatihan Budidaya Sayuran dalam Pot Bersumbu}

Pot bersumbu merupakan pot yang bagian dasarnya dipasang sumbu yang jumlahnya tergantung dari jenis tanamannya. Unit pot bersumbu terdiri dari dua bagian yaitu pot bagian atas untuk medium tanam dan tempat tanaman tumbuh sedangkan bagian bawah berupa ember/baki tempat larutan nutrisi yang diperlukan untuk pertumbuhan dan perkembangan tanaman. Adapun fungsi sumbu adalah sebagai penyerap larutan nutrisi yang ada di bagian bawah dengan prinsip kerja daya kapilaritas. Daya kapilaritas memungkinkan larutan nutrisi "naik" ke pot yang berisi medium tanam (campuran tanah, pupuk kandang dan arang sekam) dan selanjutnya diserap oleh akar tanaman untuk pertumbuhan dan perkembangannya. Pembuatan pot bersumbu dapat memanfaatkan barang-barang bekas seperti ember, kaleng cat, gallon aqua bekas dan kain kiloan tidak terpakai atau kaos sobek sebagai sumbu.

Tim warga IbM setelah mempunyai Ipteks pembibitan kemudian dibuatkan program teknik penanaman sayuran dengan menggunakan pot bersumbu (wick pot). Dalam kegiatan ini, peserta dilatih untuk melakukan transplanting bibit dengan benar sehingga kematian akibat pindah tanam dapat ditekan seminimal mungkin. Selain itu juga diberikan pengetahuan nutrisi tanaman yang diberikan pada baki tampungan di bawah pot tanaman sebagai sumber hara mineral untuk pertumbuhan dan perkembangan tanaman hingga berhasil dipanen. Komposisi media tanam yang optimal bagi tanaman juga dimasukkan sebagai materi pelatihan, termasuk konsentrasinya sehingga tanaman tidak akan mengalami defisiensi atau toksisitas konsentrasi pupuk.

Hasil kegiatan pembuatan komposisi media, tranplanting dan pertumbuhan vegetatif tanama terung ungu dalam pot bersumbu yang dilakukan warga komplek perumahan mitra IbM di bawah bimbingan tim dosen pengabdian masyarakat dari perguruan tinggi dapat dilihat transfer Ipteks sejak persiapan media tanam, pemasangan sumbu, pemberian pupuk pada baki larutan, dan pemeliharaan tanaman sudah dikuasai peserta dengan baik demikian juga dengan teknik budidaya sayuran menggunakan polybag. Indikatornya adalah pertumbuhan tanaman sayuran yang subur, hal ini terlihat dari tinggi tanaman dan ukuran daunnya yang lebar seperti disajikan pada Gambar 5 dan 6. 


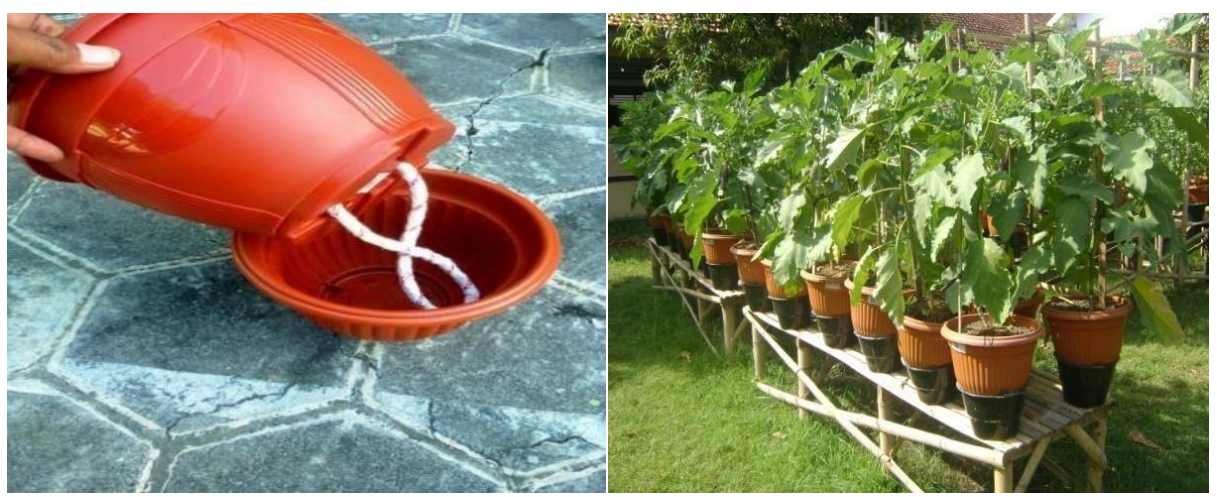

Gambar 5. Budidaya terung ungu menggunakan Pot Bersumbu

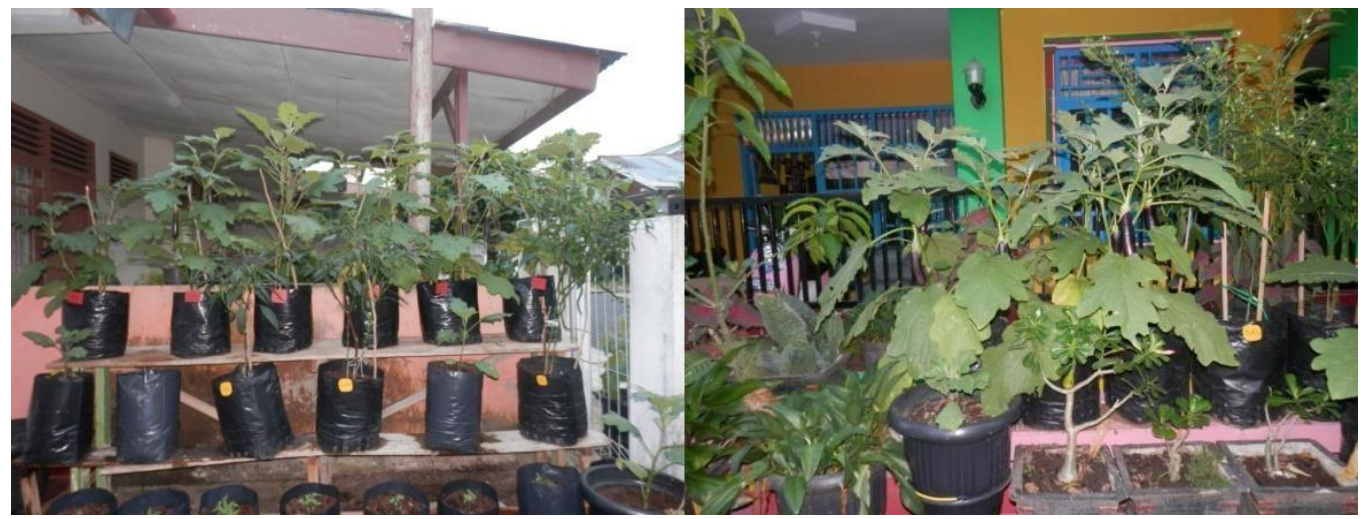

Gambar 6. Pertumbuhan terung dan cabai di depan rumah karya tim mitra IbM

Pertumbuhan vegetatif yang vigor dan kuat merupakan hasil penerapan ilmu agronomi yang diberikan tim dosen kepada tim mitra. Warga peserta IbM diberikan cara teknik pengamatan beberapa variabel pertumbuhan sebagai komponen agronomis pendukung produksi tanaman seperti: cara mengukur tinggi tanaman, diameter batang, waktu berbunga, dan hasil panen, selain itu juga pengenalan serangan hama dan penyakit pada sayuran.

Akhir dari kegiatan pengabdian kepada masyarakat tentunya ingin menujukkan bahwa program kawasan pemukiman hijau melalui penerapan program rumah pangan lestari di pemukiman perkotaan dapat menumbuhkan kesadaran warga masyarakat akan konservasi sumberdaya alam dan lingkungan, salah satu programnya adalah memberdayakan halaman ber- semen dengan tanaman sayuran dalam pot/polybag sehingga menambah luasan ruang hijau di lingkungan rumah warga yang sempit.

Lingkungan perumahan yang sehat, asri, hijau dan teduh mampu memberikan suasana yang nyaman. Pemanfaatan ruang terbuka dengan budidaya tanaman sayuran, selain bernilai ekonomi juga menciptakan lingkungan yang sehat dan edukatif bagi warga. Tanaman melalui proses fotosintesis berperan menyediakan oksigen untuk kebutuhan respirasi manusia dan menyerap karbondioksida di udara, dengan demikian keberadaan tanaman di sekitar rumah dengan halaman semen menjadikan ruangan dalam rumah dan jalan di pemukiman terasa segar, selain itu juga ijo royo-royo seperti Gambar 7. 


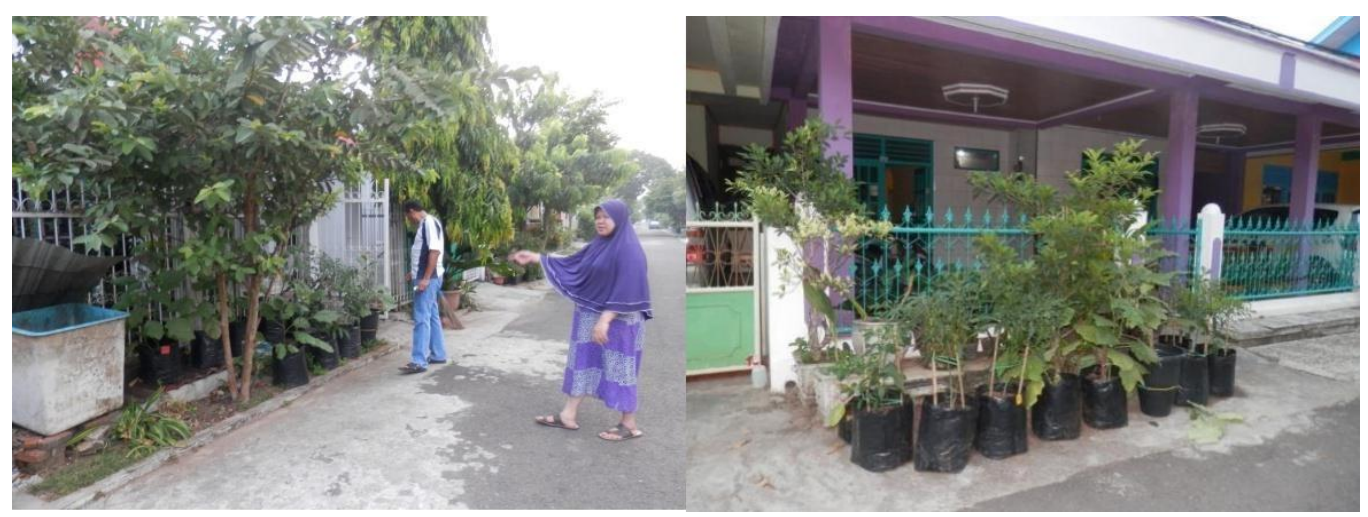

Gambar 7. Pemanfaatan lahan semen depan rumah dan sisi jalan untuk budidaya sayuran

\section{KESIMPULAN DAN SARAN}

Tim pengabdian kepada masyarakat Universitas Bengkulu dalam kegiatan pengabdian kepada masyarakat melalui skim IbM DP2M mampu melakukan alih teknologi teknik budidaya sayuarAn dalam pot bersumbu di komplek perumahan BTN Bina harapan dan Perumnas Unib Kota Bengkulu melalui program rumah pangan lestari. Program Rumah Pangan Lestari di kawasan perumahan perkotaan merupakan salah satu upaya kreatif, inovatif dan ramah lingkungan untuk mewujudkan kawasan hijau di lingkungan pekarangan perumahan yang asri, sejuk dan produktif adalah memanfaatkan pot bersumbu (wick pot) pada budidaya tanaman sayuran semi organik.

\section{UCAPAN TERIMA KASIH}

Penulis sampaikan ucapan terima kasih kepada Direktorat Riset dan Pengabdian kepada Masyarakat (DRPM), Kemristekdikti, Republik Indonesia atas bantuan finansialnya dalam pelaksanaan kegiatan yang berjudul Penerapan Program Rumah Pangan Lestari di Komplek Perumahan Btn Bina Harapan dan Perumnas Unib Kota Bengkulu dalam skema Iptek bagi masyarakat (IbM) Tahun 2015.

\section{DAFTAR PUSTAKA}

Bainbridge, D.A., 2007, A Guide for Desert and Dryland Restoration, Island Press. Eliades, A., 2010, Deep Green Permaculture, www.deepgreenpermacuture.com.

Kementerian Pertanian, 2011, Pedoman Umum Model Kawasan Rumah Pangan Lestari, Jakarta.

Lehman, J., 2007, Bio-Char Soil Management on Highly Weathered Soils in The Humid Tropics. J.Plant Nutr. Soil, p 112-121.

Perazzini, S., 2012, How to Keep Your Potted Plants Alive While You Are Away. www.remuerarealestateregister.co.nz. 
Rachman, H.P.S., dan M. Ariani, 2007, Penganekaragaman Konsumsi Pangan di Indonesia: Permasalahan dan Implikasi untuk Kebijakan dan Program, Makalah pada "Workshop Koordinasi Kebijakan Solusi Sistemik Masalah Ketahanan Pangan Dalam Upaya Perumusan Kebijakan Pengembangan Penganekaragaman Pangan“, Hotel Bidakara, Jakarta, 28 November 2007, Kementerian Koordinator Bidang Perekonomian Republik Indonesia.

Simatupang, P., 2006, Kebijakan dan Strategi Pemantapan Ketahanan Pangan Wilayah. Makalah Pembahas pada Seminar Nasional "Pemasyarakatan Inovasi Teknologi Pertanian Sebagai Penggerak Ketahanan Pangan Nasional” Kerjasama Balai Besar Pengkajian dan Pengembangan Teknologi Pertanian, Balai Pengkajian Teknologi Pertanian NTB dan Universitas Mataram, Mataram 5-6 September 2006.

Undang-Undang Republik Indonesia Nomor 18 Tahun 2012 Tentang Pangan. 